\title{
Successful Climate Change Strategies in Corporate Farming
}

\author{
DeAnn Renee Reaves \\ Walden University
}

According to the National Oceanic and Atmospheric Administration's National Centers for Environmental Information (2016), climate-related disasters occurring from 2011 to 2015 caused property damages in excess of US $\$ 230$ billion-and the agriculture sector incurs some of the largest losses (Hoffmann, 2013). The purpose of this case study was to identify, through an in-depth interview and document review, successful climate-change-based sustainability strategies in a publicly held farming operation. The findings indicated that the farm's climate-change-based sustainability strategy had basic qualities of corporate social responsibility, triple-bottom-line thinking, and systems thinking. Specific approaches identified were mitigation- and adaptation-oriented approaches. Implications for social change include prevention of food crises worldwide, particularly in areas of the world that are already vulnerable.

Keywords: climate change, social impact, sustainability, environment, business strategy

\section{Introduction}

One of the most significant problems facing all businesses is the effect of severe climate change resulting from globally increasing temperatures (Howard-Grenville, Buckle, Hoskins, \& George, 2014). Climate-related disasters occurring from 2011 to 2015 caused property damages in excess of US $\$ 230$ billion (National Oceanic and Atmospheric Administration's National Centers for Environmental Information, 2016). Agriculture is a sector incurring some of the largest losses (Hoffmann, 2013). Countless examples of extreme weather have occurred due to climate change, including droughts, flooding, heat waves, fires, and hurricanes (National Oceanic and Atmospheric Administration's National Centers for Environmental Information, 2016). As climate change threatens business, it also provides opportunities to innovate (Howden \& Jacobs, 2016; Kaesehage, Leyshon, \& Caseldine, 2014).

Using legitimacy theory as the theoretical framework, through the study entitled "Successful Climate Change Strategies in Corporate Farming in North America," I sought to identify elements and approaches of a successful climate-change-based strategy in the agricultural sector. Such elements would then be useful to other organizations in developing similar strategies. Corporate social responsibility (CSR), triple-bottom-line thinking, and systems thinking (defined in the literature review section) were identified as basic, necessary qualities, while mitigation and adaptation were distinguished as critical specific approaches in a successful climate-change-based strategy.

The core criterion used to establish success of the company's climate-change-based strategy were primarily the company's profitability, but also included the benefits to society and environment. Interview and document review (particularly the annual report) revealed that the company's profitability resulted largely from its climate-change-based strategy. Success of the strategy was also confirmed through an interview that each element of the company's climate-change-based strategy 
was selected by management after extensive analysis of social, environmental, and financial benefits.

I selected a North American publicly held corporate farm to analyze using the following criteria: (a) a climate-change-based sustainability strategy was available on the Internet at the time of the study, (b) the goal of the strategy was to improve profitability, (c) the strategy was being used to improve profitability, and (d) the highest net income of the companies available with the other listed criteria. Open-ended, semistructured interview questions and document/website review were used to collect data. The individual participant was an executive in corporate farming principally responsible for the creation and management of the climate-change-based sustainability strategy. The company will hereafter be referred to as "Company A" to protect its anonymity. Institutional review board approval was received prior to conducting the study.

The theoretical framework for this study was legitimacy theory (Dowling \& Pfieffer, 1975). Legitimacy theory originated from organizational legitimacy, which was developed by Dowling and Pfieffer. A tenet of the theory is that business behaviors result from attempting to legitimize activities based on the expecations of society (Prado-Lorenzo, Rodríguez-Domínguez, GallegoÁlvarez, \& García-Sánchez, 2009). Legitimacy theory has frequently been employed to explain organizational decisions that benefit environment or society (Dowling \& Pfeffer, 1975). The pursuit of corporate actions benefitting society or environment is normally explained using the legitimacy, stakeholder, political, or legal theory (Bani-Khalid \& Ahmed, 2017). Stakeholder, political and legal theories are among the earlier viewpoints (Bani-Khalid \& Ahmed, 2017). However, legitimacy theory is a more recent theory, which widely views such corporate actions as benefitting all of society. Climate-change-based sustainability strategies benefit society (and the environment) in generalrather than specific stakeholders or for a specific legal or political reasons-making legitimacy theory the most logical lens for exploring the motivation behind pursuing such strategies. As applied to this study, legitimacy theory holds that organizations will implement sustainability strategies or programs to legitimize business decisions based on the expectations of society.

The results of the case study offer the potential contribution to social change of prevention of food crises worldwide, particularly in areas of the world that are already vulnerable. The findings of this study could be useful in all areas of business and all sizes of agricultural operations-from small farms to corporations and agriculture across the globe.

\section{Literature Review}

This discussion comprises a review of key terms used throughout the study, impacts of climate change on agriculture, common climate change strategies used in agriculture, and risks and opportunities of climate change planning.

\section{Key Terms}

CSR is the role businesses have in ethical decisions related to society (Carroll, 2015). Triple-bottomline signifies a three-way view of measuring corporate success-societal, environmental, and economic-also called people, planet, and profit (Elkington, 1997). Systems thinking is a term used to describe the interdependence which exists in larger systems (Senge, Smith, Kruschwitz, Laur, \& Schely, 2008). Sustainability is a common term that is used to describe how businesses can effectively manage the impacts of the external environment- to continue to be profitable today while not sacrificing the needs of the future (Senge et al., 2008). Sustainability is therefore only possible if 
the natural systems are left unharmed because the corporation depends on the natural systems for survival. Climate change, a noted change in regular climate patterns, is due to a rise in average surface temperatures on earth (American Meteorological Society, 2016). Scientific consensus is that this rise in temperature is due to releases of $\mathrm{CO}_{2}$ and other greenhouse gases into the atmosphere (American Meteorological Society, 2016). For this study, the scientific consensus was considered accurate.

\section{The Agricultural Industry}

The agricultural industry will be greatly impacted by climate change (Hoffmann, 2013; Reidsma et al., 2015; Wheeler \& von Braun, 2013). Furthermore, agriculture is a significant contributor to climate change (Hoffman, 2013). Agriculture accounts for 10-12\% of the human-caused greenhouse gas emissions (Prokopy, Morton, Arbuckle, Mase, \& Wilke, 2015), and agriculture and climate change are interconnected global processes (Singh, Poonia, Kumhar, 2017). Nitrogen emissions heat up the atmosphere significantly faster than any other emissions, making agriculture a key contributor to climate change (Stuart, Schewe, \& McDermott, 2012).

Wheeler and von Braun (2013) projected that due to the rainfall irregularities and weather extremes inherent in climate change, crop production is envisaged to decrease in many areas. Those countries already experiencing hunger will experience worsening food security issues (Wheeler \& von Braun, 2013). In the past, climate change was gradual, which allowed those in the agriculture sector to adapt to the change (Anwar, Liu, Macadam, \& Kelly, 2013). However, climate events are now becoming more sudden, severe, and difficult to predict (Anwar et al., 2013).

\section{Climate Change Strategies in the Agricultural Industry}

The concepts of mitigation and adaptation are consistently mentioned in climate change strategy related literature (Busch, 2011; Robbins, 2015). Mitigation relates to attempts to prevent additional global warming (Robbins, 2015). Contrarily, adaptation refers to efforts to safeguard against dangers of climate change (Robbins, 2015). Protection of the very resources necessary to continue conducting business is an inherent part of adaptation (Busch, 2011). Adaptation and mitigation are equally important because mitigation makes adaptation less necessary (Kolk \& Pinske, 2005).

The agriculture sector has multiple strategies available to adapt to climate change (Seo, 2014). For example, crop production has historically involved decisions regarding crop selection based on current and predicted changes in weather (Seo, 2014). Adaptation measures include changing the crop mix in a particular location (Jaworski, 2016). Minimal soil tillage, no tillage, and mulch with crop rotation are effective adaptation measures (Duda et al., 2014). The difficult questions are how to adapt and how fast adaptations can occur (Seo, 2014).

Because nitrogen is the main contributor to global warming from the agricultural sector, reduction in the use of nitrogen fertilizer is a key climate mitigation strategy (Stuart et al., 2012). Effective adaptive strategies include an element of mitigation such as fertilizer management and tillage strategies (Arbuckle, Morton, \& Hobbs, 2013). There is a feedback cycle inherent in climate change as it relates to agriculture (Hamilton, Bever, Labbé, Yang, \& Yin, 2016). For example, pesticide use contributes significantly to climate change, and at the same time, climate change increases pests (Hamilton et al., 2016). These types of feedbacks create the need for complex and advanced mitigation and adaptation mechanisms in agriculture (Hamilton et al., 2016). Strategies such as increasing biodiversity, crop rotations, and cover crops, serve as mitigation and adaptation strategies 
(Prokopy et al., 2015). Arbuckle et al. (2013) suggested the best agriculture climate change strategies would be those that are a mix of adaptation and mitigation.

\section{Business Necessity for Climate Change Planning: Risks and Opportunities}

Rajput, Kaura, and Khanna (2013) examined the risk of business failure due to the lack of sustainability practices. The lack of a climate change strategy can impact a company's bottom line in a myriad of ways (American Meteorological Society, 2016). Similarly, lack of awareness of the hazards of climate change could bring wasted financial opportunities (Kaesehage et al., 2014). Cheng, Ioannou, and Serafeim (2014) found a positive relationship between CSR and lower capital constraints and cost of capital. Through CSR, systems thinking, and triple-bottom-line thinking, there is increased transparency, improved long-term focus, and innovation, which ultimately increase profit potential (Cheng et al., 2014).

\section{Method}

I used purposeful sampling to identify a North American corporate farm. In order to identify and gain access to the research participant, I began by exploring the Internet to identify the corporate farm in North America with the highest net income with a published (web-based) climate-changebased sustainability strategy. Using the corporate website, I identified the appropriate manager responsible for the creation and management of this strategy.

The data were collected through a semistructured telephone interview and document/artifact review. For the semistructured interview, the research participant was presented with a prescribed set of semistructured questions and allowed ample time to answer each question. I followed up with any queries prompted by answers to the initial questions presented. Once the data were initially collected, member checking of the data was employed by validating my understanding and exact wording with the participant. The questions are provided below. Content analysis was used, in which the interview data and document review were analyzed to identify principal themes. Finding core themes involved manually manipulating the data by continually resorting and reexamining the data into various categories. The interview questions were as follows:

Interview Question 1: Why do you have an environmentally related strategy for your farm? Interview Question 2: What steps were taken in implementing the strategy you have in place to deal with environmental impacts?

Interview Question 3: How did you determine the components of your strategy for improving profitability that include addressing the impacts to the environment?

Interview Question 4: How has your strategy benefitted the profit of your farm?

Interview Question 5: What, if any, do you consider to be other successes of your strategy (besides improving profitability).

Interview Question 6: What other comments would you like to add about your sustainability strategy?

\section{Findings}

The findings of this study both supported and contradicted the concept of legitimacy theory that business behaviors result from the tendency of organizations to display the same or similar values to those of society (Dowling \& Pfiffer, 1975). Although the results did show that the sustainability measures resulted from affirming the needs of society, several of the decisions resulted from the various stakeholders' needs and a general desire to make ethical business decisions. The findings 
confirm the themes presented in the literature review pertaining to effective sustainability strategies, particularly in terms of making decisions that impact the long-term health of the business as well as society (Cooper, 2016; Kolk \& Pinske, 2005). The themes identified from this study correspond with those identified in the literature review. As noted in the literature review, both mitigation and adaptation are needed to successfully strategize for climate change; this is because mitigation efforts ultimately make adaptation less essential (Cooper, 2016).

CSR, triple-bottom-line thinking, and systems thinking were identified as the basic necessary qualities of successful climate-change-based sustainability strategies. Specific mitigation- and adaptation-oriented approaches were identified. As reflected in Figure 1, the basic qualities of a successful sustainability strategy frame and form the aspects of the specific strategies. Thus, mitigation and adaptation sustainability strategies are successful because they reflect these general qualities. Figure 1 also illustrates how mitigation strategies are used to reduce the impact of climate change, while adaptation strategies are used to manage the immediate impacts of climate change.

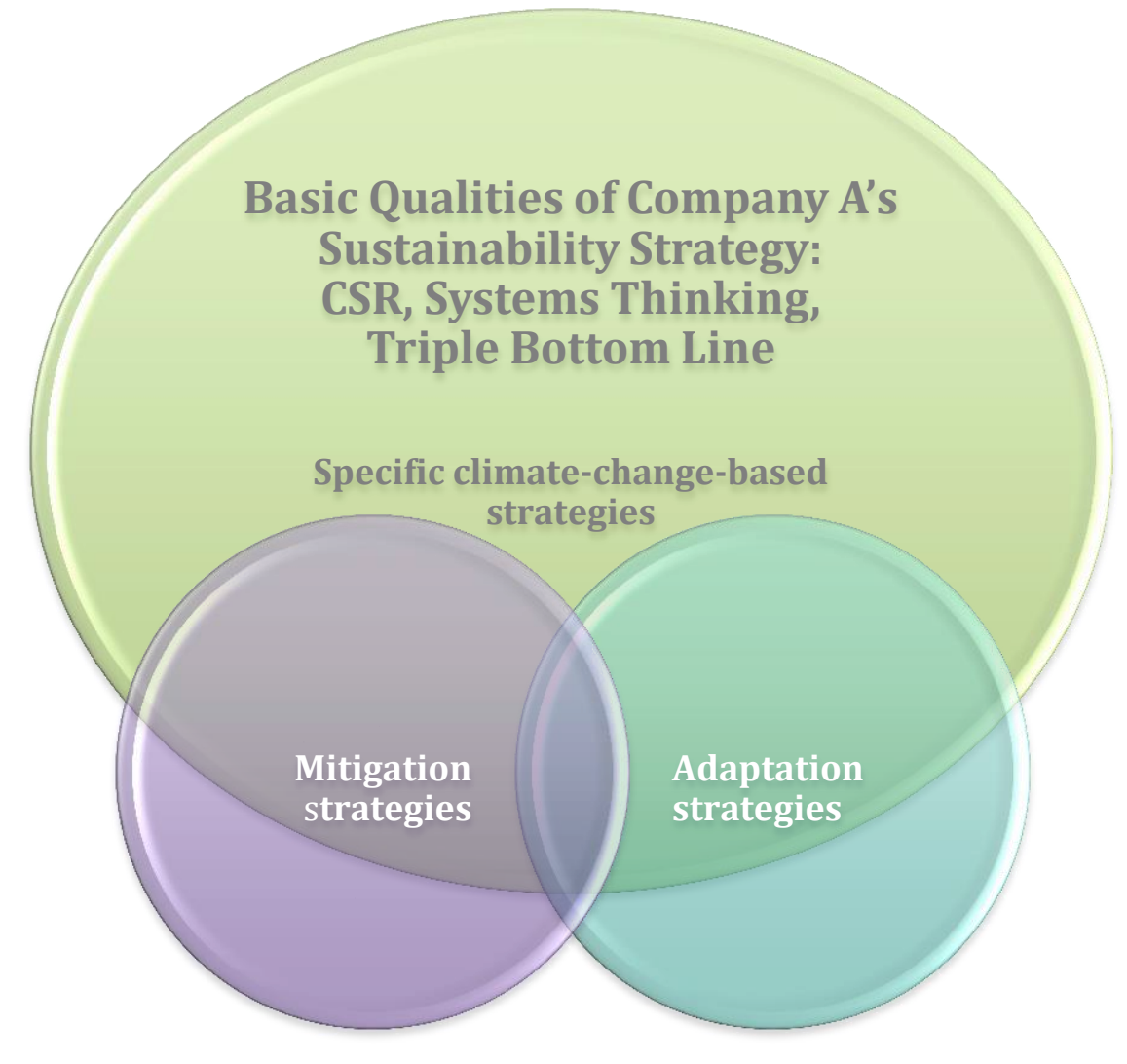

Figure 1. Relationship of Core Themes

\section{Theme 1-Sustainability Strategy Basic Qualities: Corporate Social Responsibility, Systems Thinking, Triple-Bottom-Line Thinking}

As McWilliams, Parhankangas, Coupet, Welch, and Barnum (2016) stated, once managers understand the tradeoffs inherent in making socially responsible decisions, they can implement 
competitive strategies that make sustainability possible. CSR thinking was apparent in the interview responses as well as document review. Participant interview responses included the statement, "We collaborate with community and regional stakeholders... All those investments are bringing returns through a stronger community." Both interview responses and the corporate website revealed the company's dedication to their community and society. Company A has received global certification related to farming standards since 2010, which based on the annual report, provides evidence to stakeholders (particularly customers) of respect for environmental sustainability.

Systems thinking involves anticipating any limits in resources that could affect an organization's long-term survivability (Senge et al., 2008). System limits can be societal, environmental, or involve basic resources on which a business relies (Senge et al., 2008). Interview responses included the statement, "But the company is not just in a vacuum-you are in a region-all of those people-we want to be working with them and supporting them so that everything is sustainable." It was evident in interview responses and on the corporate website the management at Company A uses systems thinking in making sustainability strategy decisions. The company's extensive sustainability program, described throughout the website, interview responses and other company documents include measures (as shown in Table 1) to value water, land, and employees as limited resources and integral parts of the overall system.

Also shown in Table 1, document review and interview responses revealed that Company A's sustainability strategy concentrates on the concept of resource, nature, and people-very similar to the fundamental pieces of the triple bottom line of people, planet, and profits. Interview responses included a statement indicating that a sustainable outlook means analyzing decisions based on impact on employees, land, and water, along with profit.

Responses to interview questions and data from corporate documents, the annual report, and the website were sorted and compiled to identify the core themes. In Tables 1 and 2, interview responses to particular questions are denoted as IQ (interview question) along with the number correlating to the question. Table 1 reveals which sources validated each quality.

\section{Table 1. Sources for Theme 1: Corporate Social Responsibility, Systems Thinking, and Triple} Bottom Line

\begin{tabular}{ll}
\hline $\begin{array}{l}\text { Corporate social responsibility } \\
\text { issue }\end{array}$ & Source \\
\hline Corporate social responsibility & $\begin{array}{l}\text { Interview responses (IQ1, IQ2, IQ3, IQ6), } \\
\text { website, annual report }\end{array}$ \\
Systems thinking & $\begin{array}{l}\text { Interview responses (IQ1, IQ2, IQ3, IQ6), } \\
\text { website, annual report, other documents } \\
\text { Interview responses (IQ3), website, other } \\
\text { corporate documents, annual report }\end{array}$ \\
\hline
\end{tabular}

Note. IQ = interview question.

\section{Theme 2-Specific Climate-Based Sustainability Strategies: Mitigation and Adaptation}

Table 2 shows that the mitigation and adaptation approaches were thoroughly covered in interview responses, the annual report, the corporate website, and other corporate documents. Mitigation efforts help the organization in the long term because mitigation will ultimately reduce long-term 
adaptation costs and total operating costs (Cooper, 2016). The primary mitigation approaches used at Company $\mathrm{A}$ are decreased carbon dioxide $\left(\mathrm{CO}_{2}\right)$ emissions, decreased nitrogen emissions, and a reduction in pesticide and herbicide use. Protecting resources threatened by climate change and managing consequences of climate change are basic qualities of adaptation measures (Busch, 2011). Key types of adaptation efforts at Company A are water conservation, soil enhancements, and business diversification.

Table 2. Sources for Theme 2: Specific Climate-Change-Based Strategies-Mitigation and Adaptation

\begin{tabular}{ll}
\hline Climate change sustainability strategy & Source \\
\hline Mitigation & $\begin{array}{l}\text { Interview responses (IQ2, IQ5, IQ7), annual } \\
\text { report, website, other corporate documents }\end{array}$ \\
Adaptation & $\begin{array}{l}\text { Interview responses (IQ2, IQ3, IQ5), annual } \\
\text { report, website, other corporate documents }\end{array}$ \\
\hline
\end{tabular}

Note. IQ = interview question.

\section{Mitigation Strategies}

Decreased $\mathrm{CO}_{2}$ emissions

$\mathrm{CO}_{2}$ is the main contributor to the increase in atmospheric temperatures (Senge et al., 2008). Due to the impact of $\mathrm{CO}_{2}$ on atmospheric temperatures, it is logical that a significant piece of the climatechange-based strategy at Company A relates to a reduction in $\mathrm{CO}_{2}$ emissions.

The company's solar panel operation is a perfect example of a business decision made with judgment based on profit with consideration for environmental impact. The interviewee responded that Company A cleared an area of unproductive crops to use for solar panels. The company's annual report revealed that these panels provide all the electricity needed for packing operations and cold storage. Document review indicated that Company A's solar panel operations sequester 2,560 tons of $\mathrm{CO}_{2}$ annually. Other $\mathrm{CO}_{2}$ reduction initiatives at Company $\mathrm{A}$, such as vertically integrating operations and ensuring sustainability within the supply chain have a less direct impact but nevertheless mitigate climate change. Vertical integration and control over supply chain sustainability are initiatives that work as mitigation, yet double as adaptation measures. Each supplier within the supply chain has an influence on the environment, according to Stuart and Schewe (2016). Similarly, having planting, packaging, processing, and shipping all in one area reduces $\mathrm{CO}_{2}$ emissions that otherwise would occur through transporting crops.

\section{Decreased nitrogen emissions}

Stuart et al. (2012) reported that nitrogen from agriculture fertilization is a major contributor to global warming and that reduction in the use of nitrogen fertilizer is a vital form of mitigation. Reducing use of fertilizer and more efficiently applying fertilizer are extremely effective mitigation techniques (Stuart \& Schewe, 2016). Reduction in fertilizer use takes many forms at Company A. Interview data and document review revealed that Company A decreases use of fertilizer and herbicides (which decreases nitrogen) through green waste recycling, fertilization analysis and scheduling, and decreasing the need for herbicides by allowing sheep to graze between solar panels. The use of sheep to control weeds is an innovative mitigation strategy which reduces the use of nitrogen-based herbicides and the emission of nitrogen. 


\section{Reduced pesticide and herbicide use}

Climate change is significantly impacted by pesticide use (Hamilton et al., 2016). Therefore, reducing the use of pesticides is a fundamental mitigation technique. In the annual report for Company A, the organization acknowledged that use of pesticides causes damage to the environment. Company A uses multiple avenues to reduce their use of pesticides. Using green waste recycling, in addition to reducing the need for fertilizers, also reduces the need for pesticides. Integrated pest management, a method in an interview response referred to as "a very important part of what they do," uses beneficial insects to control the pests which are harmful to the crops. Company A maintains a private insectary for this purpose.

Maintaining the resources necessary to conduct business in the short-term and protecting resources for the future is essential (Busch, 2011). Results from interview and document review for Company A indicated that approaches for adaptation strategies include water conservation, soil enhancement, and diversity in business endeavors. Results indicated that water conservation efforts are extensive and pervasive pieces of the overall sustainability strategy at Company A.

\section{Adaption Strategies}

\section{Water conservation}

Water is a critical resource for agriculture. As climate change impacts the availability of water in this sector, it becomes even more critical to protect this resource (Baldos \& Hertel, 2014). As noted in the annual report of Company A, severe weather can cause drought which can devastate agriculture operations. Water conservation efforts at Company A, based on interview responses and document review, include natural wastewater treatment, micro emitters, irrigation water analysis, water monitoring and scheduling, groundwater monitoring and protection, water basin management, and dense planting of crops.

Interview responses indicated that Company A uses a wastewater treatment system in which the use ultraviolet light, gravity, and plant material to treat grey water in ponds. The water is then suitable for irrigation purposes, but otherwise would be wasted. This is an example of an innovative approach to adaptation. Company A manages their access to water in other innovative ways that include the use of technology. The monitoring, scheduling, and analysis of irrigation are examples of incorporating technology into water conservation efforts. Use of micro emitters, a form of drip irrigation technology, distributes water efficiently. Review of the company's annual report also revealed the use of water exchanges and transfers within their water management program. The annual report indicated that actively managing water supplies for changing conditions has created a low level of risk related to water supply. Dense planting of crops is another method used by Company A to decrease use of water because less water is wasted in the space between crops. Document review indicated that Company A plants crops four times the traditional amount per acre. Using mulch from the green waste recycling program also reduces the need for water at Company A, due to the water retention qualities of mulch. Water conservation efforts are a valuable adaptation measure particularly as water becomes more scarce (Baldos \& Hertel, 2014).

\section{Soil enhancements}

A range of soil enhancement measures is employed by Company A for climate change adaptation. Document review indicated the use of mulch not only reduces the need for water but actually lowers the temperature of the soil. Mulching as an adaptation measure should increase in value as global temperatures increase. Mulching is an example of an adaptation that also mitigates the effects of climate change because reduction in soil temperature has a direct effect on air temperature. Enhancing the fertility of soil provides a stronger atmosphere for crops to cope with the impacts of 
climate change (Müller et al., 2016). Company A also uses crop rotation and diversity in planting regions as soil enhancement methods. Planting crops in diverse regions is an important adaptation method as the dangers of climate change can impact some regions with drought and other regions with flooding (Altieri \& Nicholls, 2017). Company A plants crops in different regions in the United States and has partners globally. This adaptation measure as noted on the company website: "ensures that if any region is impacted by adverse weather conditions, we are able to maintain a constant source of supply for our customers." Similarly, it has been shown that implementing plant diversity practices reduces vulnerability from severe climate episodes (Altieri \& Nicholls, 2017).

\section{Diversification of business endeavors}

Both diversity in planting regions and diversity in business endeavors were referred to as contributing to "economic resiliency" by Company A. Economic resiliency (Robbins, 2015) is a concept that is similar to adaptation measures since these endeavors serve to safeguard the company against adverse effects related to climate change. Planting in diverse regions, as noted on the company website, "ensures that if any region is impacted by adverse weather conditions, we are able to maintain a constant source of supply for our customers." Company A also participates in separate but related business endeavors.

Company A has a community development division and provides housing for employees. The company also leases their land, provides sustainability education programs, and bee-keeping operations. The annual report for Company A indicated that their housing and land rental operations "provide a consistent, dependable source of cash flow that helps to counter the volatility typically associated with an agricultural business." These endeavors are ideal as adaptation measures as they counter the risk involved in the impact of climate change on the agricultural operations of the company. Community development and employee housing also serve as mitigation efforts because within these communities, common destinations are within walking distancedecreasing the need for fossil fuels.

\section{Discussion}

\section{Limitations}

The key limitation of the study is the limited number of publically held, corporate farms available to research. Because the study did not include all forms of agricultural operations, further research could include privately held and family farms, operations in other countries, and using multiple-case designs.

\section{Future Research}

Future research could also include new sustainability technologies such as hydroponic agriculture (in which soil is not used) and vertical agriculture (in which food is grown indoors in stacked layers). Other recommended areas for study include new sustainability technologies such as hydroponic agriculture (in which soil is not used) and vertical agriculture (in which food is grown indoors in stacked layers). I also recommend that future researchers conduct studies identifying and exploring barriers preventing agricultural organizations from pursuing a climate-change-based sustainability strategy. 


\section{Social Implications}

Agriculture is an industry critically impacted by climate change-depending heavily on the health of the environment-further intensifying the need for successful climate-change-based strategies. Implications for social change include decreased danger of starvation and malnutrition of people in underdeveloped areas. As the future of agriculture threatens food production and food security worldwide, the importance of developing a successful climate-change-based strategy cannot be overemphasized.

\section{Conclusion}

The study results provided an important and useful example of a successful strategy-one with a foundation reflecting values other than profit-as reflected in CSR, triple-bottom-line thinking, and systems thinking. The study reveals that specific adaptation and mitigation approaches advance the strategy's effectiveness by protecting resources and assisting with prevention of future climate change. The hope is that managers in agriculture will be motivated and inspired to pursue elements from this study or similar strategies.

\section{References}

Altieri, M. A., \& Nicholls, C. I. (2017). The adaptation and mitigation potential of traditional agriculture in a changing climate. Climatic Change, 140, 33-45. doi:10.1007/s10584-0130909-y

American Meteorological Society. (2016). Climate change risk management. Retrieved from https://www.ametsoc.org/ams/index.cfm/policy/studies-analysis/climate-change-riskmanagement

Anwar, M. R., Liu, D. L., Macadam, I., \& Kelly, G. (2013). Adapting agriculture to climate change: A review. Theoretical and Applied Climatology, 113, 225-245. doi:10.1007/s00704-012-0780-1

Arbuckle, J. G., Morton, L. W., \& Hobbs, J. (2013). Understanding farmer perspectives on climate change adaptation and mitigation: The roles of trust in sources of climate information, climate change beliefs, and perceived risk. Environment and Behavior, 47, 205-234. doi:10.1177/0013916513503832

Baldos, U. C., \& Hertel, T. W. (2014). Global food security in 2050: The role of agricultural productivity and climate change. Australian Journal of Agricultural \& Resource Economics, 58, 554-570. doi:10.1111/1467-8489.12048

Bani-Khalid, T. \& Ahmed, A. (2017). Corporate social responsibility (CSR): A conceptual and theoretical shift. International Journal of Academic Research in Accounting, Finance and Management Sciences, 7, 203-212. doi:10.6007/IJARAFMS/v7-i1/2626

Busch, T. (2011). Organizational adaptation to disruptions in the natural environment: The case of climate change. Scandinavian Journal of Management, 27, 389-404.

doi:10.1016/j.scaman.2010.12.010

Carroll, A. B. (2015). Corporate social responsibility. Organizational Dynamics, 44, 87-96.

Cheng, B., Ioannou, I., \& Serafeim, G. (2014). Corporate social responsibility and access to finance. Strategic Management Journal, 35, 1-23. 
Cooper, M. (2016). The economic and institutional foundations of the Paris agreement on climate change: The political economy of roadmaps to a sustainable electricity future. Retrieved from https://papers.ssrn.com/sol3/Delivery.cfm/SSRN_ID2722880_code1777798.pdf?abstractid=27 $22880 \&$ mirid $=1$

Dowling, J., \& Pfeffer, J., (1975). Organizational legitimacy: Societal values and organizational behaviour. Pacific Sociological Review, 18, 122-136. doi:10.2307/1388226

Duda, B., Rusu, T., Bogdan, I., Pop, A., Moraru, P., Giurgiu, R., \& Coste, C. (2014). Considerations regarding the opportunity of conservative agriculture in the context of global warming. Research Journal of Agricultural Science, 46, 210-217.

Elkington, J. (1997). Cannibals with forks. The triple bottom line of 21st century business. Retrieved from http://appli6.hec.fr/amo/Public/Files/Docs/148_en.pdf

Hamilton, C., Bever, J., Labbé, J., Yang, X., \& Yin, H. (2016). Agriculture, ecosystems \& environment. 216, 304-308. doi:10.1016/j.agee.2015.10.006

Hoffmann, U. (2013). How to transform agriculture under the challenges of global warming: A review of key development and trade issues. Journal of International Commerce, Economics \& Policy, 4, 1-26. doi:10.1142/S1793993313500130

Howard-Grenville, J., Buckle, S. J., Hoskins, B. J., \& George, G. (2014). Climate change and management. Academy of Management Journal, 57, 615-623. doi:10.5465/amj.2014.4003

Howden, M., \& Jacobs, K. L. (2016). Innovations in assessment and adaptation: Building on the U.S. national climate assessment. Climatic Change, 135, 157-171. doi:10.1007/s10584-015-1519-7

Jaworski, A. (2016). Encouraging climate adaptation through reform of Federal Crop Insurance subsidies. New York University Law Review, 91, 1684-1718.

Kaesehage, K., Leyshon, M., \& Caseldine, C. (2014). Communicating climate change-learning from business: Challenging values, changing economic thinking, innovating the low carbon economy. Fennia, 192, 81-99. doi:10.11143/40867

Kolk, A., \& Pinkse, J. (2005). Business responses to climate change: Identifying emergent strategies. California Management Review, 47, 6-20 doi:10.2307/41166304

McWilliams, A., Parhankangas, A., Coupet, J., Welch, E., \& Barnum, D. T. (2016). Strategic decision making for the triple bottom line. Business Strategy and the Environment, 25, 193-204. doi:10.1002/bse1867

Müller, A., Bautze, L., Meier, M., Gattinger, A., Gall, E., Chatzinikolaou, E., ... Ullmann, L. (2016). Organic farming, climate change mitigation and beyond: Reducing the environmental impacts of EU agriculture. Retrieved from https://www.ifoameu.org/sites/default/files/ifoameu_advocacy_climate_change_report_2016.pdf

National Oceanic and Atmospheric Administration National Centers for Environmental Information (NCEI) U.S. Billion-Dollar Weather and Climate Disasters (2019). Retrieved from https://www.ncdc.noaa.gov/billions/

Prado-Lorenzo, J., Rodríguez-Domínguez, L., Gallego-Álvarez, I., \& García-Sánchez, I. (2009). Factors influencing the disclosure of greenhouse gas emissions in companies worldwide. Management Decision, 47, 1133-1157. doi:10.1108/00251740910978340

Prokopy, L. S., Morton, L. W., Arbuckle, J. G., Mase, A. S., \& Wilke, A. K. (2015). Agricultural stakeholder views on climate change: Implications for conducting research and outreach. 
Bulletin of the American Meteorological Society, 96, 181-190. doi:10.1175/BAMS-D-1300172.1

Rajput, N., Kaura, R., \& Khanna, A. (2013). Indian banking sector towards a sustainable growth: A paradigm shift. International Journal of Academic Research in Business and Social Sciences, 3, 290-304.

Reidsma, P., Wolf, J., Kanellopoulos, A., Schaap, B. F., Mandryk, M., Verhagen, J., \& van Ittersum, M. K. (2015). Climate change impact and adaptation research requires integrated assessment and farming systems analysis: A case study in the Netherlands. Environmental Research Letters, 10, 045004.

Robbins, A. (2015). How to understand the results of the climate change summit: Conference of Parties21 (COP21) Paris 2015. Journal of Public Health Policy, 37, 129-132.

Senge, P., Smith, B., Kruschwitz, N., Laur, J., \& Schely, S. (2008). The necessary revolution: How individuals and organizations are working together to create a sustainable world. New York, NY: Doubleday.

Seo, S. N. (2014). Adapting sensibly when global warming turns the fields brown or blue: A comment on the 2014 IPCC Report. Economic Affairs, 34, 399-401. doi:10.1111/ecaf.12087

Singh, M., Poonia, M. K., \& Kumhar, B. L. (2017). Climate change: Impact, adaptation and mitigation: A review. Agricultural Reviews, 38, 67-71. doi:10.18805/ag.v0iOF.7309

Stuart, D., \& Schewe, R. L. (2016). Constrained choice and climate change mitigation in U.S. agriculture: Structural barriers to a climate change ethic. Journal of Agricultural and Environmental Ethics, 29, 369-385. doi:10.1007/s10806-016-9605-z

Stuart, D., Schewe, R. L., \& McDermott, M. (2012). Responding to climate change barriers to reflexive modernization in U.S. agriculture. Organization \& Environment, 25, 308-327. doi:10.1177/1086026612456536

Wheeler, T., \& von Braun, J. (2013). Climate change impacts on global food security. Science, 341, 508-513. doi:10.1126/science.1239402

The Journal of Social Change, sponsored by Walden University, welcomes manuscripts focusing on interdisciplinary research in social change that improves the human condition and moves people, groups, organizations, cultures, and society toward a more positive future.

Walden University Publishing: http://www.publishing.waldenu.edu 